\title{
TINDAK TUTUR “REQUEST” BAHASA INGGRIS DALAM METODE ROLE PLAY PADA MAHASISWA KEPERAWATAN
}

\author{
Maria Theresia Priyastuti \\ STIKes St. Elisabeth Semarang, Jln. Kawi No. 11 Semarang, Jawa Tengah, Indonesia 50232 \\ *priyastuti.maria@gmail.com
}

\begin{abstract}
This research discusses the form of request and the strategy of request in English learning process using role play method. Objective: to describe the form of request and the strategy of request in English learning process using role play method. Method: descriptive qualitative with equal pragmatic methods using theory of Edmondson and House and Aijmer. The data were taken from role play conversation which contained speech act of request. The total sampling were used 20 groups when the nursing students did role play of giving health education. Data methods used listening and direct observation (participatory observation). Results: firstly, speech acts of assertive request in English learning that often used in role play conversations are "you can .., you must (have to), you should ... you had better" and tentative requests for speech acts are "can you ...?, And would you ...?". Secondly The speech act of the request strategy asserts that it is possible for the hearer to do something and asks for permission to do something. Conclusions: the form and the strategy of requests are found in English learning process using role play method.
\end{abstract}

Keywords: the form; the strategy; request; speech act

\section{PENDAHULUAN}

Kesopanan memiliki peran penting dalam kehidupan manusia. Kesopanan tidak hanya dilakukan oleh salah satu kelompok masyarakat, tapi juga semua orang dalam kehidupan mereka. Kesopanan dipandang sebagai sesuatu yang menyenangkan dan dibutuhkan dalam kegiatan berkomunikasi dan berinteraksi sosial dengan menggunakan bahasa sebagai alat percakapan mereka sehari-hari. Thomas (1995: 150) menyatakan bahwa "kesopanan adalah tujuan dunia nyata untuk menyenangkan orang lain atau sebagai motivasi yang mendasari perilaku linguistik seseorang". Kesopanan dapat membuat pendengar memberikan respon yang baik. Menurut Yule (1996), kesopanan menunjukkan kesadaran wajah orang lain yang terkait dengan jarak sosial atau kedekatan. Kesopanan mengacu pada perasaan emosional dan sosial diri dalam membangun hubungan baik dengan orang lain.

Kesopanan berbahasa yang merupakan bagian dari kaidah sosial dan juga sebagai strategi berbahasa mempunyai peranan yang sangat penting dalam proses komunikasi. Dengan menggunakan kesopanan berbahasa baik penutur (speaker) maupun petutur (listener) akan merasa saling menghargai. Oleh sebab itu pengetahuan tentang kaidah sosial pemakaian bahasa, yang berkaitan dengan kesantunan berbahasa penting sekali dipahami oleh pemakai bahasa, terutama pembelajar bahasa Inggris. Pengajar perlu membekali pembelajar dengan kompetensi komunikatif yang memperhatikan kesopanan berbahasa dalam bertutur. Kesopanan merupakan salah satu bentuk request dan termasuk dalam jenis strategi tindak tutur meminta (request).

Permintaan (request)oleh Bach and Harnish (1979) digambarkan sebagai tindak tutur (speech act) yang mengekspresikan harapan penutur bahwa petutur melakukan sesuatu dengan persyaratan bahwa petutur melakukan keinginan yang diharapkan sebagai alasan bertindak. Permintaan merupakan sebuah ekspresi yang di dalamnya terkandung suatu maksud agar mitra tutur bertindak. Sebuah permintaan dapat diwujudkan dalam kalimat imperatif, interogatif, dan deklaratif (Wierzbicka dalam Primantari, 2016). Permintaan dikatakan langsung jika modus kalimat yang digunakan adalah imperatif sedangkan permintaan dikatakan tidak langsung jika modus kalimat yang digunakan adalah bukan imperatif, melainkan deklaratif dan interogatif (Wijana dalam Primantari, 2016). Permintaan adalah tindakan 
yang menyatakan harapan pembicara pada pendengar sehubungan dengan tindakan prospektif baik secara verbal atau non-verbal (Blum-Kulka dalam Ayuningtias, 2012) Meminta dapat diartikan bahwa pendengar dapat menolak untuk mematuhinya (Lyons dalam Ayuningtias, 2012). Tindak tutur request sebagai kata atau kalimat sopan untuk bertanya. Terdapat empat kondisi untuk membuat permintaan dengan sopan dapat dilakukan yaitu 1) pembicara ingin tindakan dilakukan; 2) pembicara percaya pendengar dapat melakukan tindakan; 3) pembicara percaya bahwa pendengar ingin melakukan tindakan; dan 4) pembicara percaya bahwa pendengar tidak akan melakukan tindakan kecuali diminta. Kondisi permintaan yang sopan yang pertama disebut berbasis pembicara dan permintaan ketiga dan keempat disebut sebagai pendengar (Khaliba : 2014). Menurut Searle (1969) request kata kerja performatif dikaitkan dengan aturan sebagai berikut :

Persiapan 1. H dapat melakukan A. Dia percaya bahwa H mampu melakukan A

2. Tidak jelas bagi $\mathrm{S}$ dan $\mathrm{H}$ bahwa dia akan melakukan $\mathrm{A}$

Dalam kondisi normal atas kemauannya sendiri. Ketulusan $\mathrm{S}$ ingin $\mathrm{H}$ melakukan sesuatu. Keperluan dianggap sebagai upaya $\mathrm{H}$ melakukan A. Jenis tindak tutur request dikategorikan dalam jenis tindak tutur direktif. Tindak tutur direktif adalah bentuk tindak tutur yang memiliki maksud bahwa penutur berharap pendengar melakukan apa yang diinginkan penutur (Rullianti, 2014; Amelia, 2018). Kata kerja yang masuk dalam tindak tutur direktif meliputi order, request, demand, beg, advise, offer, etc (Searle, 1976). Tindak tutur request ini termasuk tindak tutur tidak langsung direktif yang memberikan kemungkinan penolakan (Searle dalam Amelia, 2018). Bentuk tuturan meminta disampaikan oleh penutur untuk memperoleh sesuatu kepada lawan tutur. Penutur menyampaikan permintaan baik secara langsung ataupun tidak langsung dengan pernyataan (A'yuni, 2017). Trosberg (dalam Alzeebaree 2017: 7314) menyatakan bahwa ada empat jenis tindak tutur request yaitu : (1) langsung meliputi "obligation, performative, dan imperative", (2) tidak langsung konvensional (berbasis pendengar) meliputi "ability, willingness, permission dan suggestion", (3) tidak langsung konvensional (berbasis pembicara) meliputi "wishes, dan desires/needs", dan (4) tidak langsung meliputi "hints". Karatepe (dalam Koç, 2011) menyatakan tiga bentuk permintaan yaitu "can, could, and would". Bentuk tindak tutur request ada 2 macam yaitu assertif/lanigsung dan tentatif. Tindak tutur request asertif merupakan bentuk request yang mengekspresikan harapan penutur secara langsung tanpa memperhatikan petutur. Pemarkah dalam bentuk kalimat deklaratif termasuk dalam tindak tutur request asertif. Bentuk tindak tutur request tentatif merupakan bentuk tindak tutur request dimana harapan dan pilihan petutur diperhatikan dan mengandung beberapa pemarkah tidak langsung (Edmondson \& House, 1981).

Tabel 1.

Ekspresi bentuk tindak tutur request asertif dan tentatif

\begin{tabular}{cc}
\hline Assertive & Tentative \\
\hline I want you to & you haven't got \\
I ask you to & is it possible for you to \\
I want (need) & would you mind \\
You must (have to) & if you would \\
You had better & I would be grateful if you \\
You should & would you \\
& will you \\
& could you \\
& Can you
\end{tabular}

Strategi request ini merupakan arti dan bentuk konvension strategi (Clark 1979). Didalam teori tindak tutur, penekanan bentuk konvension alami ini dinamakan kata kerja performatif sedangkan bentuk konvension formal dinamakan prosodi, urutan kata (word order), dll. Berikut ini adalah 18 strategi request yang dikaitkan dengan fungsinya. Fungsi definisi request ini untuk mengelompokkan request atau untuk menjelaskan strategi apa yang digunakan untuk membuat request. Menurut Aijmer (1969) strategi tindak tutur request terdiri atas 1) menanyakan tentang kemampuan pendengar untuk 
melakukan sesuatu (kemampuan) e.g. can you ..... 2) menanyakan tentang kemungkinan tindakan yang diinginkan terjadi (konsultasi) e.g. is it possible ..., you haven't got ..., would you mind ..., have you ... 3) menanyakan apakah pendengar mau melakukan sesuatu atau memiliki keberatan untuk melakukan sesuatu (kesediaan) e.g. will you ..., would you (like) .., 4) menyatakan keinginan bahwa agen harus melakukan sesuatu (keinginan) e.g. I would like you to ... 5) menyatakan kebutuhan atau keinginan untuk sesuatu (kebutuhan) non-verbal e.g I want ..., I need ..., 6) yang menyatakan bahwa pendengar berkewajiban untuk melakukan tindakan yang diinginkan (kewajiban) e.g. you must ..., you have to ..., 7) menyatakan bahwa sudah sepantasnya pendengar melakukan tindakan yang diinginkan (kesesuaian) e.g. you should ...., 8) menanyakan idiomatik dengan menggunaakan kalimat pertanyaan Wh. e.g. what about ..., why not ..., how about ...., why don't you ..., 9) merujuk pada tindakan hipotetis (hipotesis) e.g. if you would ..., perhaps you would ...., 10) menyatakan bahwa seseorang akan menghargai, senang, merasa bersyukur jika hipotesis tindakan yang diinginkan dapat direalisasikan (penghargaan) e.g. I would be grateful if you would ...., I would be glad if ....11) meminta izin untuk melakukan sesuatu (pertanyaan meminta izin) e.g. may I ...., let me ...could I..., 12) menyatakan kemungkinan bagi pendengar untuk melakukan sesuatu (kemungkinan) e.g. you may ...., you can ... 13) merujuk pada pendapat pembicara bahwa sesuatu lebih disukai (preferensi) e.g. you had better ...., the best thing to do ... 14) merujuk secara eksplisit pada tindakan meminta (performatif) e.g. I was going to suggest .... 15) merujuk pada keadaan dunia yang perlu diubah (kondisi/keadaan) e.g. there are (some scented rushes) 16) memberi nama objek yang diminta (penamaan) e.g. (the next slide) please 17) memeriksa ketersediaan objek yang diinginkan, dll. (ada) e.g. is (Mrs Davy) there 18) lainnya (misalnya memberikan justifikasi untuk permintaan). Cara penutur membuat sebuah kalimat permintaan (request) dipandang sebagai harapannya untuk menjadi sopan. Sasaki, Rintell and Mitchell (dalam Koç : 2011) menyatakan strategi request yang sering digunakan adalah "would you...?" and "could you...?".

Pembelajaran bahasa Inggris dengan English for Specific Purposes bagi mahasiswa keperawatan diberikan di semester tertentu sebagai mata kuliah dasar umum (MKDU) di STIKes St. Elisabeth. Salah satu metode pembelajaran bahasa Inggris yang sering digunakan dosen adalah metode role play. Metode role play ini dilakukan oleh mahasiswa keperawatan dengan menggunakan alat bantu medis untuk membantu mahasiswa memahami prosedur keperawatan dengan baik. Penggunaan metode role play dengan alat medis membuat mahasiswa keperawatan menjadi semakin terlatih dalam menguasai ketrampilan berbahasa Inggris. Salah satu materi dalam metode role play yang diajarkan pada mahasiswa adalah kegiatan pendidikan kesehatan. Pada materi ini mahasiswa bermain peran (role play) sebagai perawat belajar untuk menyampaikan rekomendasi atau saran/nasehat maupun larangan pada pasien dengan menggunakan bentuk dan strategi tindak tutur.

Bentuk dan strategi tindak tutur request dapat terjadi kendala jika pemahaman mahasiswa terhadap makna yang disampaikan dalam tindak tutur tidak direspon sesuai harapan penutur. Mahasiswa sebagai penutur sering menggunakan tuturan yang kurang sopan dalam membuat permintaan kepada pasien sebagai petutur. Hal ini membuat peneliti tertarik untuk melakukan penelitian mengenai penggunaan bentuk/jenis dan strategi tindak tutur meminta (request) antara perawat dan pasien yang muncul dalam proses pembelajaran Bahasa Inggris dengan metode role play. Penggunaan tindak tutur meminta (request) untuk mengetahui bentuk request dan strategi request yang muncul dalam proses pembelajaran bahasa Inggris dengan metode role play dalam bidang keperawatan.

\section{METODE}

Metode penelitian ini adalah penelitian deskriptif kualitatif. Penelitian kualitatif adalah penelitian yang mendeskripsikan atau menggambarkan fenomena atau hubungan antar fenomena yang diteliti secara sistematis, faktual dan akurat (Sugiarto dan Kusmayadi, 2009:29). Pengumpulan data dilakukan dengan menggunakan teknik observasi partisipatif yaitu teknik dimana peneliti melibatkan 
diri dalam suatu lingkungan penelitian sambil mengamati apa yang terjadi dalam lingkungan tersebut (Heslin, 2007), sehingga secara langsung peneliti mampu menilai kemampuan mahasiswa dalam penerapan teknik role play. Selain itu pengumpulan data menggunakan teknik rekam dan catat.

Populasi penelitian ini adalah mahasiswa Program Studi DIII Keperawatan Stikes St. Elisabeth Semarang yang mengambil mata kuliah Bahasa Inggris II dengan pembelajaran menggunakan salah satu metode yaitu metode role play. Sampel data dalam penelitian ini menggunakan total sampling 20 kelompok. Data diperoleh melalui metode percakapan yang mengandung tindak tutur meminta yang berlangsung dalam proses pengajaran mata kuliah Bahasa Inggris dengan bahan kajian pemberian pendidikan kesehatan pada pasien.

Metode pengumpulan data digunakan adalah metode simak dan pengamatan langsung (observasi partisipasif). Menurut Sudaryanto (dalam Muhammad, 2011) peneliti melakukan pengamatan dan melihat langsung ke lokasi penelitian untuk memperoleh data. Tahapan-tahapan dalam pengumpulan data adalah 1) mengumpulkan data dengan pencatatan transkripsi data, 2) memilih dan memilah data percakapan yang mengandung tindak tutur request, 3) menganalisis data menurut bentuk request dan strategi request. Metode analisis data yang digunakan padan pragmatis, dengan memperhatikan percakapan antara penutur dan petutur. Metode padan pragmatik digunakan untuk menginterpretasikan makna penggunaan tindak tutur request dan metode penyajian hasil analisis data yang digunakan adalah metode informal.

\section{HASIL DAN PEMBAHASAN}

Hasil penelitian, data yang muncul adalah ekspresi bentuk tindak tutur 'request' yang digunakan oleh sebagian besar mahasiswa adalah bentuk tindak tutur request asertif berupa ucapan "you can, you must (have to), you had better, you should". Permintaan yang terkandung di dalam penanda "you can, you must (have to), you had better, you should" mengandung ekspresi yang memiliki maksud agar mitra tutur bertindak. Penanda permintaan tersebut termasuk dalam permintaan tidak langsung karena modus kalimat yang digunakan adalah deklaratif. Bentuk tindak tutur request asertif "you can" menempati urutan paling atas penggunaan bentuk tindak tutur asertif dalam pembelajaran bahasa Inggris dengan metode role play. Berikut adalah contoh dialog tindak tutur request asertif.

$N$ : you can exercise three times a week for example jogging, swimming, cycling $P:$ OK nurse $(D 8 / 31)$

Bentuk tindak tutur request tentatif hanya ditemukan dalam percakapan menggunakan pemarkah seperti "can you, dan would you". Penanda "can you, dan would you" termasuk dalam permintaan tidak langsung karena modus kalimat yang digunakan adalah interogatif. Berikut adalah contoh dialog tindak tutur request tentatif.

$N$ : can you explain me what you should consume?

$P$ : I should consume green leafy vegetables such as spinach, broccoli, and so on. (D7/12)

Strategi tindak tutur request yang digunakan dalam pembelajaran bahasa Inggris dengan metode role play adalah sebagai berikut.

1. Menanyakan tentang kemampuan pendengar untuk melakukan sesuatu (kemampuan)

Percakapan dengan menggunakan "Can you" ada 12 ucapan $=10,9 \%$

Contoh:

$P \quad:$ Can you explain me about the good food for your health?

$N \quad$ : Yes, of course (D11/5)

2. Menanyakan apakah pendengar bersedia melakukan sesuatu atau memiliki keberatan untuk melakukan sesuatu (kesediaan).

Percakapan dengan menggunakan "Would you" ada 1 ucapan $=0,9 \%$

Contoh :

$N$ : would you roll your sleeve up?

$P \quad: \operatorname{Yes}(D 9 / 1)$ 
3. Menyatakan bahwa pendengar berkewajiban untuk melakukan tindakan yang diinginkan (kewajiban)

Percakapan dengan menggunakan you must ada 2 ucapan $=1,8 \%$

Contoh :

$P \quad$ : Should I consume it regularly?

$N$ : Yes, you must arrange the diet to make your body balance (D7/2)

Percakapan dengan menggunakan you have to ada 10 ucapan $=9,1 \%$

Contoh :

$P \quad:$ What kind of food should I avoid?

$N$ : you have to avoid junkfood, soft drink and instant coffee (D1/1)

4. Menyatakan bahwa sudah sepantasnya/sebaiknya pendengar melakukan tindakan yang diinginkan (kesesuaian)

Percakapan dengan menggunakan "you should" ada 4 ucapan $=3,6 \%$

Contoh :

$P \quad$ : What should I drink?

$N$ : you should drink fresh water or some juice (D2/1)

5. Meminta izin untuk melakukan sesuatu (menggunakan pertanyaan untuk meminta izin)

Percakapan dengan menggunakan "may" ada 2 ucapan $=1,8 \%$

Contoh :

$N$ : May I get your name, please?

$P \quad: M r$. Tony please $(D 7 / 5)$

Percakapan dengan menggunakan"Can I" ada 15 ucapan $=13,6 \%$

Contoh :

$\mathrm{N}$ : you can consume green leafly vegetables for example broccoli, spinach, or you can consme another vegetable such as carrot, asparagus

$\mathrm{P}$ : If I'm bored with this menu, can I combine them, nurse/ (D5/6)

6. Menyatakan kemungkinan bagi pendengar untuk melakukan sesuatu (kemungkinan)

Percakapan dengan menggunakan "you may" ada 2 ucapan $=1,8 \%$

Contoh :

$\mathrm{P}$ : What kind of foods must I consume, nurse ?

$\mathrm{N}$ : you may consume animal processed products such as egg,cheese, or milk (D3/1)

Percakapan dengan menggunakan"you can" ada 60 ucapan $=54,5 \%$

Contoh :

$\mathrm{P}$ : Then, what should I eat?

$\mathrm{N}$ : for your luch, you can eat chicken soup, low fat meat, sandwich, rice (D5/7)

7. Merujuk pada pendapat pembicara bahwa sesuatu lebih disukai (preferensi)

Percakapan dengan menggunakan "you had better" ada 1 ucapan $=0,9 \%$

Contoh :

$\mathrm{N}$ : you had better consume more fibrous foods in order to help the process of your digestive tract

P : okey, nurse (D6/1)

Setiap kegiatan pembelajaran bahasa Inggris dengan metode role play dengan bahan kajian pemberian Penkes telah menghasilkan berbagai tindak tutur permintaan baik bentuk dan strategi. Percakapan alami dengan metode role play menghasilkan interaksi diskusi antar penutur dengan menggunakan strategi request (Lestari, 2019). Bentuk tindak tutur permintaan yang sering digunakan adalah percakapan dengan menggunakan pemarkah "you can" sedangkan bentuk tindak tutur permintaan lain adalah percakapan dengan menggunakan pemarkah can you ... ?, would you ...?, dan you had better ... sedangkan strategi tindak tutur request lebih banyak menyatakan tentang kemungkinan bagi pendengar untuk melakukan sesuatu dan meminta izin untuk melakukan sesuatu. Permintaan seseorang untuk melakukan sesuatu digunakan penanda "can/could you ...?" atau dapat 
menggunakan "will" dan "would". Permintaan meminta izin berarti meminta seseorang untuk mengizinkan atau minta izin untuk melakukan sesuatu. Tindakan meminta izin digunakan untuk kepentingan pembicara karena pembicara akan mengambil sebuah tindakan (Amelia, 2018).

Pemakaian bentuk tindak tutur request "you can.., you must (have to).., you should.., you had better" termasuk dalam tindak tutur langsung karena tindak tutur tersebut memunculkan fungsinya secara harfiah dan langsung sedangkan tindak tutur "can you ... ?, dan would you ...?" termasuk dalam tindak tutur tidak langsung yang menunjukkan aspek kesopanan. Strategi tindak tutur request yang memuat unsur kesopanan dari percakapan di atas lebih dipengaruhi oleh 1)penggunaan sebuah pertanyaan selain kalimat deklaratif, 2)pemilihan sebuah saran/nasehat (suggestion), 3)pemilihan kata bantu modal (modal auxiliary), 4)pemilihan subjek, 5)memberikan alasan untuk melakukan sesuatu, 6) menghaluskan kekuatan tindak tutur yang tidak biasa/impositif.

Bentuk dan strategi tindak tutur dalam contoh percakapan diatas melibatkan peran perawat $(\mathrm{N})$ dan peran pasien (P) dalam pelaksanaan kegiatan role play. Bentuk dan strategi tindak tutur ini menyiratkan bahwa selain situasi yang diberikan kepada mahasiswa dalam kegiatan role play, jumlah mahasiswa yang terlibat dalam kegiatan role play juga dapat mempengaruhi jumlah tindak tutur permintaan yang dapat dihasilkan dalam percakapan bahasa Inggris. Mahasiswa memiliki kemampuan terbatas untuk menghasilkan tindak tutur permintaan sehingga mereka cenderung meniru pola percakapan yang sama dalam melakukan tindakan permintaan.

\section{SIMPULAN}

Peneliti dapat menyimpulkan bahwa bentuk tindak tutur permintaan asertif dalam pembelajaran bahasa Inggris yang sering digunakan dalam percakapan role play adalah " you can.., you must (have to).., you should.., you had better" dan tindak tutur permintaan tentatif adalah "can you ... ?, dan would you ...?". Srategi tindak tutur request lebih banyak menyatakan kemungkinan dan meminta izin untuk melakukan sesuatu. Bentuk dan strategi tindak tutur request perlu untuk dikaji secara lebih mendalam untuk melihat unsur pragmatik kebahasaan.

\section{UCAPAN TERIMAKASIH}

Penelitian dapat terlaksana berkat pendanaan dari LPPM Stikes St. Elisabeth Semarang. Peneliti mengucapkan terima kasih kepada LPPM Stikes St. Elisabeth Semarang dan berbagai pihak yang terlibat dalam penelitian ini.

\section{DAFTAR PUSTAKA}

Aijmer, K. (1969). Why is actually so popular in spoken English ? In Tottie and Backlund. London : Longman

Ali, Muhammad. (2011). Memahami Riset Perilaku dan Sosial. Bandung : Pustaka CendikiaUtama.

Alzeebaree, Yaseen, Yavuz, Mehmet Ali. (2017). Realization of the Speech Acts of Request and Apology by Middle Eastern EFL Learners. EURASIA Journal of Mathematics, Science and Technology Education. Vol. 13 (11). Page 7313-7327.

Amelia, Firqo, \& Firdaus, Ahmad Y. (2018). Speech Act of Requests Found in Different Rating Films Academic. Journal Perspective, Language, Education and Literature. Vol 6 (2)

A’yuni, Nia B. Q., Parji. (2017). Tindak Tutur Ilokusi Novel Surga yang Tidak Dirindukan Karya Asma Nadia (Kajian Pragmatik). Linguista. Vol.1. No.1. hal 6-11.

Ayuningtias, Diah Ikawati. (2012). Politeness Strategy in Request: Does It Always Work Well?. Prosodi Jurnal Ilmu Bahasa dan Sastra. Vol 6. No 2.1 
Bach, K \& Robert M Harnish. (1979). Linguistics Communication and Speech Acts. Cambridge MIT Press.

Clark, H.H. (1979). Responding to indirect speech acts. Cognitive Psychology. New York : Harcout inc.

Dalton-Puffer, Christiane. (2003). Telling Each Other to Do Things in Class: Directives in Content and Language Integrated Classroom. Vienna English Working Paper, 12 (1), 3-23.

Edmondson.W.J. and House J. (1981). Let's talk and talk about it : A Pedagogic Interactional Grammar of English. Munchen : Urban \& Schwarzenberg.

Henslin, James M. (2007). Sosiologi dengan Pendekatan Membumi. Surabaya : Erlangga.

Khaliba, Farahnaz Mohd., Tayehb, Asma. (2014). Indirectness in English Requests among Malay University Students . Procedia - Social and Behavioral Science. ELSEVIER. 134 page 44 -52.

Koç, E. M. (2011). Politeness in requests: A Cross-cultural study of Turkish and British Natives. Egitim Arastirmalari-Eurasian Journal of Educational Research. Issue 42, Page 153-166.

Lestari , Windy Alviora., Sembodo Thomas J. P. (2019). Request Strategies in the TV Series Victorious. LEXICON Journal. Volume 6. Number 1. Page 69-77

Primantari, Adista Nur., Wijana, I Dewa Putu. (2016). Perbandingan Bentuk Tindak Tutur Meminta oleh Pembelajar BIPA dari Korea dan Penutur Asli Bahasa Indonesia: Kajian Bahasa Antara. Kajian Linguistik dan Sastra. Vol. 1. No. 2. Hal. 95-104

Rullianti, Merry \& Sunarti. (2014). The Speech Act in David Cameron's Speech. Literary Criticism journal. Vol. 1. No.1.

Searle, J.(1969). Speech Acts: An Essay in the Philosophy of Language. Cambridge: Cambridge University Press.

Searle, J. (1976). A Classification of Illocutionary Acts. Language in Society. Cambridge: Cambridge University Press

Sugiarto, Endar dan Kusmayadi. (2000). Metodologi Penelitian Dalam Bidang Pariwisata. Jakarta: PT Gramedia Pustaka Utama

Thomas, J. (1995). Meaning in Interaction: An Introduction to Pragmatics. New York : Longman.

Yule, G. (1996). Pragmatics. New York: Oxford University Press. 
Journal of Language and Health, Vol 1 No 1, April 2020, pp. 21 - 28

Global Health Science Group 